\title{
THE EFFECT OF COENZYME Q10 AND/OR SILYMARIN ON RENALASE GENE EXPRESSION OF CARDIORENAL SYNDROME IN ADULT MALE ALBINO RATS
}

\author{
By
Gehan A. Youssef, Mona G. Al Anany, Ghada M. M. Salah El-din and Sara N. M. Mousa

Physiology Department, Faculty of Medicine (Girls), Al Azhar University, Cairo, Egypt

\begin{abstract}
Background: Therapeutic strategies in cardiorenal syndrome (CRS) should be directed to the cardio-renal connectors like renalase. Coenzyme Q10 (CoQ10) and silymarin are natural anti-oxidant and antiinflammatory agents.

Objectives: Assessing the effect of CoQ10 and/or Silymarin on renalase gene expression in CRS induced by high fructose diet (HFD) in male rats.

Patients and Methods: Fifty adult male albino rats of local strain were divided into 5 equal groups and subjected to the following regimens for 8 weeks: Group I: Supplemented orally with $1 \mathrm{ml}$ of $2 \%$ aqueous solution of tween 80 . Group II: Received HFD in the form of $30 \%$ fructose in drinking water. Group III: Received HFD and CoQ10 orally at a dose of $20 \mathrm{mg} / \mathrm{kg} /$ day dissolved in $2 \%$ tween-80 aqueous solution. Group IV: Received HFD and Silymarin orally at a dose of $200 \mathrm{mg} / \mathrm{kg} /$ day dissolved in $2 \%$ tween- 80 aqueous solution. Group V: Received HFD and both CoQ10 and silymarin in the same regimen as described before.

Results: CoQ10 and/or Silymarin significantly decreased plasma lipid profile, cardiac troponin-I, creatinine, malondialdehyde (MDA) \& tumor necrosis factor alpha (TNF- $\alpha$ ) levels when compared to HFD group. On the other hand, CoQ10 and/or silymarin caused significant increase in plasma catalase level \& renalase gene expression in kidney tissue when compared to HFD group. They also improved HFD -induced cardiac and renal fibrosis.

Conclusion: CoQ10 and Silymarin induced improvement in HFD-induced CRS as they possessed cardioprotective, reno-protective, hypo-lipidimic, anti-oxidant, anti-inflammatory and anti-fibrotic activities, as well as increased renalase expression.
\end{abstract}

Key words: Coenzyme Q10; Silymarin; Renalase; Cardiorenal Syndrome; High fructose diet.

\section{INTRODUCTION}

The maintenance of cardiovascular and renal hemostasis is dependent upon fine interactions between the heart and kidney (Hadjiphilippou and Kon, 2015). Cardiorenal syndrome (CRS) is a clinico- pathologic disorder in which a primary insult in the kidney or in the heart initiates a series of secondary functional and morphologic responses in the other organ (Athwani et al., 2017). Several mechanisms are involved in the pathophysiology of CRS such as 
hemodynamic mechanism, neurohormonal adaptations, oxidative stress and inflammation, endothelial dysfunction and atherosclerosis (Naranjo et al., 2017).

High fructose diet (HFD) induces CRS (Jia et al., 2014). It can lead to some problems as risk factors for kidney and cardiac dysfunction such as obesity, hyperuricemia, dyslipidemia, hypertension, diabetes mellitus, and induces inflammation and oxidative stress (Yerlikaya et al., 2017).

Coenzyme Q10 (CoQ10) is a vitaminlike substance presents in most eukaryotic cells especially in the mitochondria. CoQ10 is essential for energy production in electron transport chain (Pahari et al., 2016). Also, CoQ10 is considered the only lipid-soluble anti-oxidant produced by humans. It acts as an anti-inflammatory agent (Farsi et al., 2017). It is a potent gene regulator and improves human immunity. CoQ10 supplementation can be used due to its neuro-protective, anticarcinogenic, anti-diabetic, and hepatoprotective effects (Garrido-Maraver et al., 2014).

Silymarin is a natural polyphenolic flavonoid isolated from Silybum marianum. Silymarin has anti-oxidant, anti-inflammatory and anti-apoptosis properties (Razavi and Karimi, 2016). It also has immune-modulatory and antifibrotic activities. Silymarin can be used as hepato-protective, neuro-protective and anti-diabetic agent (Darvishi-Khezri et al., 2017).

Renalase is a new renal hormone with mono-amine oxidase (MAO) activity (Dziedzic et al., 2017). Kidney is the main organ of renalase expression and secretion, but its expression also takes place in other tissues such as heart, vascular endothelium, liver and nervous system (Skrzypczyk et al., 2017). Renalase can metabolize circulating catecholamines and act as a cytokine to regulate cell functions (Wu et al., 2018). Decreased renalase level leads to deleterious longterm effects on heart and kidney which finally causes CRS (Wybraniec and Mizia-Stec, 2016).

The aim of the present study was to clarify the effect of CoQ10 and/or silymarin on renalase gene expression in CRS induced by HFD in male rats.

\section{PATIENTS AND METHODS}

\section{Animals:}

The present study was conducted on fifty adult male rats of local strain (weighing 120 - 160 grams). Rats were kept in suitable stainless steel cages $(50 \times 50 \times 65 \mathrm{~cm}$ in size, 5 rats per cage) . Rats were kept for one week under prevailing atmospheric conditions before the start of the experiment to ensure laboratory acclimatization.

Rats were housed under appropriate conditions of controlled humidity. They were maintained at constant room temperature and suitable illumination conditions (normal light/dark cycle). Rats were allowed to ordinary rat chow and fresh tap water ad-libitum. The present study was carried out in the animal house of Physiology Department, Faculty of Medicine (Girls), Al-Azhar University.

\section{Drugs:}

Fructose was purchased as powder from Specialized Food Industry Company (King M); Badr City, Egypt. Tween 80 was purchased as solution from ADWIC 
Company; Cairo, Egypt. It can be used as a vehicle to emulsify hydrophobic substances (Freitag et al., 2015). CoQ10 was purchased as capsules from MEPACO Company; Sharkeya, Egypt. Silymarin (Legalon) was purchased as capsules from CID Company; Giza, Egypt.

\section{Experimental Design:}

The rats were divided into 5 equal groups and subjected to the following regimens for 8 weeks ( 6 consecutive days /week): Group I (control group): Rats fed on ordinary rat chow with free access to tap water. Each rat was supplemented orally with $1 \mathrm{ml}$ of $2 \%$ aqueous solution of tween 80 /day. Group II (HFD group): Rats received HFD in the form of $30 \%$ fructose in drinking water (Cho et al., 2017). Group III (CoQ10 group): Rats received HFD and CoQ10 orally at a dose of $20 \mathrm{mg} / \mathrm{kg} / \mathrm{day}$ dissolved in $2 \%$ tween80 aqueous solution (Singh, 2015). Group IV (Silymarin group): Rats received HFD and Silymarin orally at a dose of 200 $\mathrm{mg} / \mathrm{kg} /$ day dissolved in $2 \%$ tween- 80 aqueous solution (Jamila et al., 2017). Group V (CoQ10 \& Silymarin group): Rats received HFD with CoQ10 and Silymarin in the same regimen as described before.

The body weight of the rats were measured and recorded weekly for all groups. At the end of the experimental period, rats were fasted for 12 hours, and then blood samples were collected under light ether anesthesia from retro-orbital sinuses by capillary tubes (Simmons and Brick, 1970). The spurting blood was collected in ethylene diamine tetra-acetic acid (EDTA) coated tubes and centrifuged at $3500 \mathrm{rpm}$ for $15 \mathrm{~min}$ for plasma collection. Samples were stored frozen at 80 ?C until biochemical analysis.

\section{Biochemical analysis:}

Plasma high density lipoprotein cholesterol (HDL-C), triglycerides and total cholesterol levels were measured by quantitative-enzymatic-colorimetric procedure (França et al., 2018). They measured by using colorimetric assay kits from Cayman Chemical Company, Calbiochem Company and BioMed diagnostic Company respectively. Plasma low density lipoprotein cholesterol (LDLC) was calculated from the values of total cholesterol, HDL-c and triglycerides using Friedewald equation: LDL-C $(\mathrm{mg} / \mathrm{dl})=$ (total cholesterol) - $($ HDL-C) (triglycerides/5) (Friedewald et al., 1972). Plasma cardiac troponin I level was measured by quantitative determination using a rat cardiac troponin-I enzymelinked immunosorbent assay (ELISA) kit from Kamiya Biomedical Company (Collinson et al., 2001). Plasma creatinine level was determined using a creatinine kit from BioMed diagnostic Company (Schirmeister et al., 1964). Plasma MDA and catalase levels were detected by colorimetric method using kits from Biodiagnostic Company (Aebi, 1984). Plasma TNF- $\alpha$ level was measured by quantitative measurement using a rat TNF- $\alpha$ ELISA kit from Ray-Biotech Company (Engelmann et al., 1990).

Polymerase chain reaction (PCR) technique:

For detection of renalase gene expression in kidney tissue, RNA was extracted, reversely transcribed into cDNA and amplified by PCR, and then detected using agarose gel electrophoresis (Bustin et al., 2009). 


\section{Histo-pathological examination:}

Heart and kidney tissue specimens were collected for histological examination by the light microscope. Specimens were fixed in $10 \%$ neutral buffered formalin and processed for paraffin thin sections (Bancroft and Stevens, 1996). Sections were stained with masson's trichrome for detection of connective tissue deposits and fibrosis (Hu et al., 2019).

\section{Statistical Analysis:}

Statistical analysis was done by using statistic package for social science version 20 (SPSS, 20) for windows. Statistical analysis of variance between mean values of different groups was performed using one-way analysis of variance (ANOVA) followed by Bonferroni Post Hoc test. Quantitative data were expressed by mean \pm standard deviation (S.D.). The values of $\mathrm{P}<0.05$ were considered statistically significant.

\section{RESULTS}

I- HFD caused significant increase in plasma lipid profile, cardiac troponin-I, creatinine, MDA and TNF- $\alpha$ levels, and significant decrease in plasma catalase level and renalase gene expression in kidney tissue when compared to control group. HFD caused insignificant changes in body, heart and kidney weights when compared to control group.

II- Administration of CoQ10 and/or Silymarin caused significant decrease in plasma lipid profile, cardiac troponin-I, creatinine, MDA and TNF$\alpha$ levels, and significant increase in plasma catalase level and renalase gene expression in kidney tissue when compared to HFD group. CoQ10 and/or Silymarin caused insignificant changes in body, heart and kidney weights when compared to HFD group.
III- Co-administration of CoQ10 and Silymarin caused insignificant changes in body, heart and kidney weights, plasma triglycerides, total cholesterol, LDL-C, cardiac troponin-I, creatinine, MDA, catalase and TNF- $\alpha$ levels, while it caused significant increase in plasma HDL-C level and renalase gene expression when compared to CoQ10 group.

IV- Co-administration of CoQ10 and Silymarin caused insignificant changes in body, heart and kidney weights, plasma total cholesterol, LDL-C, cardiac troponin-I, creatinine, MDA and catalase levels, while it caused significant decrease in plasma triglycerides and TNF- $\alpha$ levels, and caused significant increase in plasma HDL-C level and renalase gene expression when compared to Silymarin group. 
THE EFFECT OF COENZYME Q10 AND/OR SILYMARIN ON...

Table (1): Effect of HFD, CoQ10 and/or Silymarin on different parameters

\begin{tabular}{|c|c|c|c|c|c|}
\hline $\begin{array}{l}\text { Groups } \\
\text { Parameters }\end{array}$ & $\begin{array}{l}\text { Group I } \\
\text { (Control } \\
\text { group) }\end{array}$ & $\begin{array}{c}\text { Group II } \\
\text { (HFD group) }\end{array}$ & $\begin{array}{c}\text { Group III } \\
\text { (CoQ10 group) }\end{array}$ & $\begin{array}{c}\text { Group IV } \\
\text { (Silymarin group) }\end{array}$ & $\begin{array}{c}\text { Group V } \\
\text { (CoQ10 \& } \\
\text { Silymarin group) }\end{array}$ \\
\hline $\begin{array}{c}\text { Body weight } \\
(\mathrm{g})\end{array}$ & $176.5 \pm 9.14$ & $177 \pm 20.57$ & $173.5 \pm 21.08$ & $171.5 \pm 13.75$ & $169 \pm 22.82$ \\
\hline $\begin{array}{c}\text { Heart weight } \\
\text { (g) }\end{array}$ & $0.557 \pm 0.04$ & $0.562 \pm 0.09$ & $0.566 \pm 0.07$ & $0.551 \pm 0.04$ & $0.556 \pm 0.04$ \\
\hline $\begin{array}{c}\text { Kidney weight } \\
\text { (g) }\end{array}$ & $1.102 \pm 0.21$ & $1.169 \pm 0.22$ & $1.112 \pm 0.21$ & $1.136 \pm 0.2$ & $1.1 \pm 0.15$ \\
\hline $\begin{array}{l}\text { Triglycerides } \\
(\mathbf{m g} / \mathbf{d l})\end{array}$ & $61.8 \pm 9.8$ & $109.7^{\mathrm{a}} \pm 14.5$ & $82.7^{\mathrm{a}, \mathrm{b}} \pm 8.69$ & $88.8^{\mathrm{a}, \mathrm{b}} \pm 8.71$ & $69.4^{\mathrm{b}, \mathrm{d}} \pm 10.77$ \\
\hline $\begin{array}{c}\text { Total } \\
\text { cholesterol } \\
(\mathrm{mg} / \mathrm{dl})\end{array}$ & $140.6 \pm 15.07$ & $235.5^{\mathrm{a}} \pm 36.83$ & $180.4^{\mathrm{a}, \mathrm{b}} \pm 21.53$ & $174.4^{\mathrm{a}, \mathrm{b}} \pm 18.88$ & $166.9^{b} \pm 17.45$ \\
\hline $\begin{array}{l}\text { HDL-C } \\
\text { (mg/dl) }\end{array}$ & $58.6 \pm 3.56$ & $25.2^{\mathrm{a}} \pm 5.39$ & $36.4^{\mathrm{a}, \mathrm{b}} \pm 7.04$ & $40^{\mathrm{a}, \mathrm{b}} \pm 4.98$ & $49.6^{\mathrm{a}, \mathrm{b}, \mathrm{c}, \mathrm{d}} \pm 8.59$ \\
\hline $\begin{array}{l}\text { LDL-C } \\
\text { (mg/dl) }\end{array}$ & $69.64 \pm 17$ & $188.36^{\mathrm{a}} \pm 39.36$ & $127.46^{\mathrm{a}, \mathrm{b}} \pm 26$ & $116.64^{\mathrm{a}, \mathrm{b}} \pm 19.17$ & $103.42^{\mathrm{a}, \mathrm{b}} \pm 18.41$ \\
\hline $\begin{array}{c}\text { Cardiac } \\
\text { troponin I } \\
(\mathbf{n g} / \mathrm{ml}) \\
\end{array}$ & $0.019 \pm 0.01$ & $0.088^{a} \pm 0.02$ & $0.037^{b} \pm 0.01$ & $0.037^{\mathrm{b}} \pm 0.01$ & $0.029^{b} \pm 0.01$ \\
\hline $\begin{array}{c}\text { Creatinine } \\
(\mathrm{mg} / \mathrm{dl})\end{array}$ & $0.1650 \pm 0.05$ & $1.6390^{\mathrm{a}} \pm 0.71$ & $0.5790^{\mathrm{b}} \pm 0.22$ & $0.5240^{\mathrm{b}} \pm 0.18$ & $0.3070^{\mathrm{b}} \pm 0.11$ \\
\hline $\begin{array}{l}\text { MDA (nmol } \\
\text { /ml) }\end{array}$ & $5.539 \pm 1.71$ & $80.4^{\mathrm{a}} \pm 22.81$ & $27.7^{\mathrm{a}, \mathrm{b}} \pm 9.85$ & $35.46^{\mathrm{a}, \mathrm{b}} \pm 15.3$ & $24.51^{\mathrm{a}, \mathrm{b}} \pm 6.93$ \\
\hline $\begin{array}{c}\text { Catalase } \\
(\mathrm{U} / \mathrm{ml})\end{array}$ & $192.78 \pm 19.44$ & $86.04^{\mathrm{a}} \pm 17.4$ & $173.04^{\mathrm{b}} \pm 15.87$ & $173.87^{\mathrm{b}} \pm 15.42$ & $188.75^{\mathrm{b}} \pm 15.56$ \\
\hline TNF- $\alpha(\mathrm{pg} / \mathrm{ml})$ & $31.84 \pm 4.22$ & $116.61^{\mathrm{a}} \pm 14.24$ & $67.49^{\mathrm{a}, \mathrm{b}} \pm 12.43$ & $78.29^{\mathrm{a}, \mathrm{b}} \pm 11.74$ & $60.4^{\mathrm{a}, \mathrm{b}, \mathrm{d}} \pm 12.19$ \\
\hline $\begin{array}{c}\text { Renalase gene } \\
\text { expression }\end{array}$ & $1.026 \pm 0.06$ & $0.292^{\mathrm{a}} \pm 0.12$ & $0.674^{\mathrm{a}, \mathrm{b}} \pm 0.1$ & $0.669^{\mathrm{a}, \mathrm{b}} \pm 0.11$ & $0.843^{\mathrm{a}, \mathrm{b}, \mathrm{c}, \mathrm{d}} \pm 0.09$ \\
\hline
\end{tabular}


Histo-pathological results:

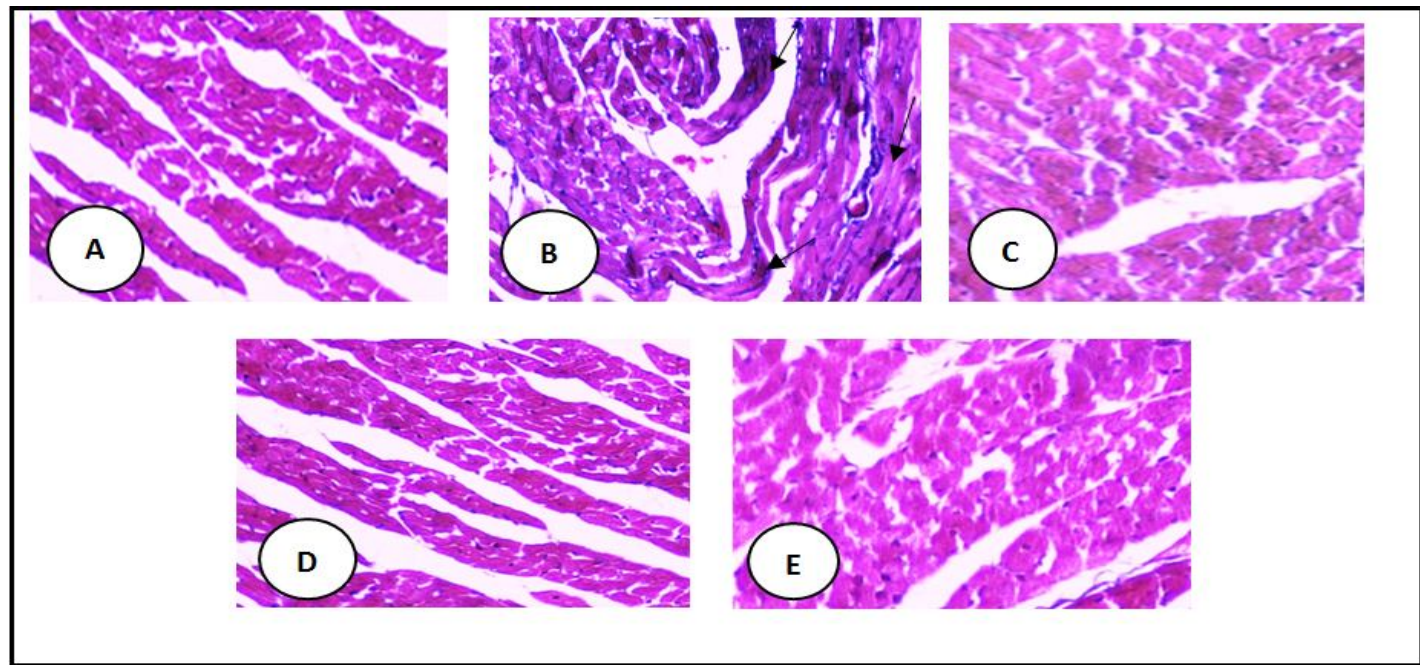

Figure (1): Microscopic examination of cardiac tissues: (A) Control group showing normal density of very thin collagen fibers in-between the cardiac muscle fibers, (B) HFD group showing marked fibrosis in-between the disorganized cardiac muscle fibers (arrows), while there were marked improvement in (C) CoQ10 group, (D) Silymarin group, and (E) CoQ10 \& Silymarin group (Masson's trichrome-X 100).
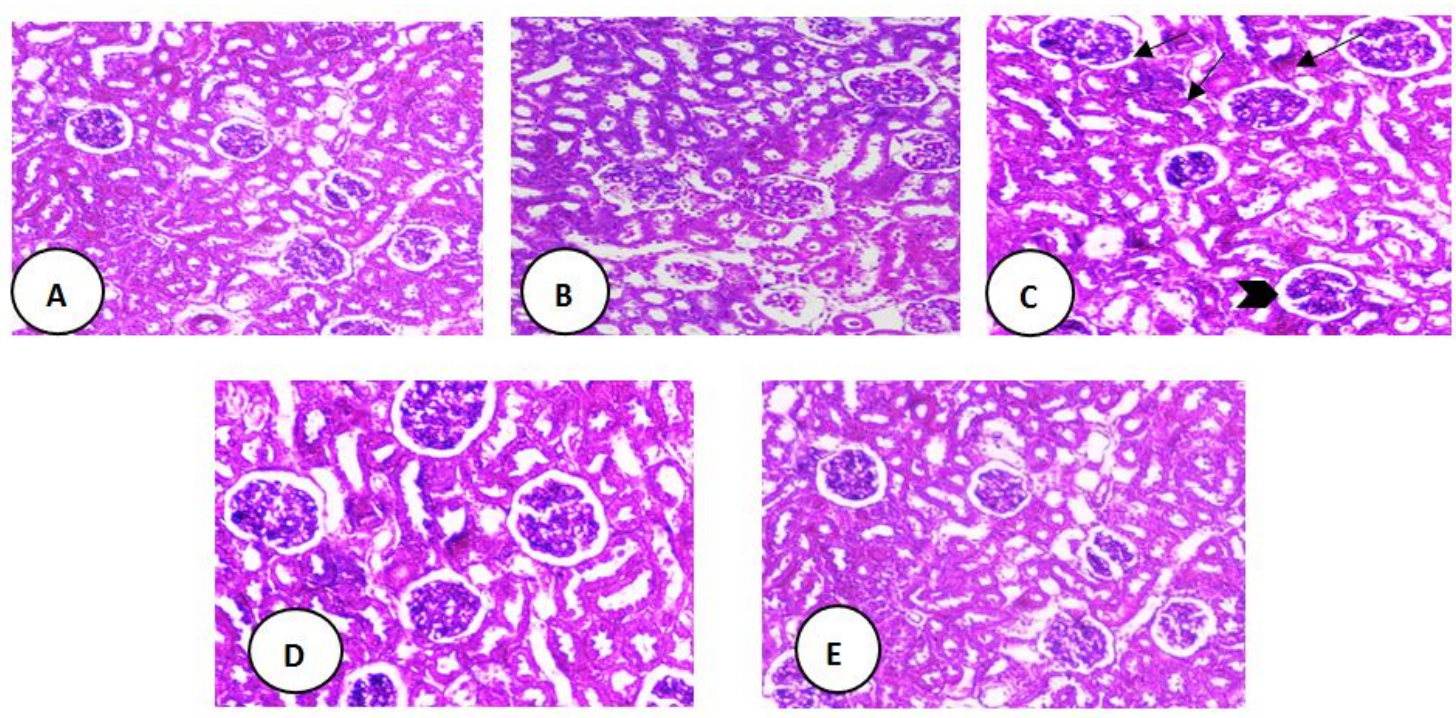

Figure (2): Microscopic examination of kidney tissues: (A) Control group showing normal density of very thin collagen fibers in the tubular wall, (B) HFD group showing marked fibrosis in the tubule-interstitial tissues (arrows) besides shrunken renal corpuscles (arrow head), while there were marked improvement in (C) CoQ10 group, (D) Silymarin group, and (E) CoQ10 \& Silymarin group (Masson's trichrome-X 100). 


\section{DISCUSSION}

In the present study, HFD caused insignificant changes in body, heart and kidney weights when compared to control group. This agreed with Chou et al. (2018) and Jensen et al. (2018) results. HFD induced dyslipidemia. (Chen et al., 2017) stated that HFD augmenting lipogenesis through up-regulating liver $\mathrm{X}$ receptor $-\alpha \quad($ LXR $-\alpha)$. HFD caused increase of cardiac troponin-I level. (Park et al., 2018) mentioned that HFD induced this result by inactivation of $5^{\prime}$ adenosine monophosphate-activated protein kinase (AMPK) signaling pathway .

HFD caused increase of creatinine level. Yang et al. (2015) explained that HFD can increase renal expression of renal urate transporter 1 (URAT1) and causes hyper-uricemia which induces inflammation and subsequently kidney injury and dysfunction .

HFD induced oxidative stress in this work agreed with Kosuru et al. (2018) who reported that HFD induces peroxidation that results in increased MDA level. HFD induced inflammation which agreed with Jensen et al. (2018) and Suriano et al. (2018) who reported that HFD increases intestinal bacterial overgrowth and permeability. So, it can facilitate translocation of bacterial endotoxins to the liver which stimulates Kupffer cells leading to inflammatory response and cytokines production .

HFD in the present work caused significant decrease in renalase gene expression in kidney tissue when compared to control group. To our knowledge, this was the first study to detect the effect of HFD on renalase gene expression which may be explained by the fibrosis observed in the kidney tissues of HFD group. Wu et al. (2017) reported that the expression level significantly diminishes in sub-totally nephrectomized rats due to the progressive renal fibrosis. Xie (2017) reported that HFD induced fibrosis through stimulation of alpha smooth muscle-actin ( $\alpha$-SMA).

In the present study, CoQ10 caused insignificant changes in body, heart and kidney weights when compared to HFD group which agreed with Garjani et al. (2011) and Barden et al. (2018). CoQ10 caused hypolipidemic effect which agreed with Rahmani et al. (2018) who reported that CoQ10 induces gene expression of peroxisome proliferator-activated receptor- $\gamma$ (PPAR- $\gamma)$ that inhibits lipogenesis. CoQ10 showed decrease in creatinine and cardiac troponin-I levels which agreed with Fatima et al. (2015) and Tachampa et al.(2018) who attributed these effects to the anti-oxidant and antiinflammatory properties of $\mathrm{CoQ} 10$.

CoQ10 in this work showed antioxidant activity. Hormozi et al. (2018) attributed this effect to the ability of CoQ10 to regenerate endogenous antioxidants such as vitamins $\mathrm{C}$ and $\mathrm{E}$. Administration of CoQ10 showed antiinflammatory activity. Rahmani et al. (2018) attributed this effect to the inhibition of nuclear factor kappa-lightchain-enhancer of activated B cells (NFкB) pathway by CoQ10 .

CoQ10 caused significant increase in renalase gene expression in kidney tissue when compared to HFD group. To our knowledge, this is the first study to detect the effect of CoQ10 on renalase gene expression. CoQ10 showed anti-fibrotic 
activity. (Chen et al., 2018) attributed this effect to the inhibition of transforming growth factor beta 1 (TGF- $\beta 1$ ) expression by CoQ10.

In the present study, Silymarin caused insignificant changes in body, heart and kidney weights when compared to HFD group which agreed with Wang et al. (2018) results. Silymarin caused hypolipidimic effect. Sharma et al. (2018) attributed this effect to the suppression of 3-hydroxy-3-methylglutaryl-coenzyme A (HMG-CoA) reductase activity by Silymarin.

Silymarin showed decrease in cardiac troponin-I and creatinine levels. Avci et al. (2017) and Ustyol et al. (2017) attributed these effects to the anti-oxidant and antiapoptotic properties of silymarin .

Silymarin showed anti-oxidant activity by decreasing MDA level and increasing catalase level. Vivekanandan et al. (2018) attributed this effect to the ability of Silymarin to restore non-enzymatic antioxidant levels such as reduced glutathione, vitamins C, A and E. Kwon et al. (2013) stated that Silymarin enhances hepatic reduced glutathione generation by elevating cysteine availability and inducing cystine synthesis.

Silymarin showed anti-inflammatory activity. Zhang et al. (2013) attributed this effect to the inhibition of NF- $\mathrm{B}$ pathway by silymarin. Silymarin caused significant increase in renalase gene expression in kidney tissue when compared to HFD group. To our knowledge, this is the first study to detect the effect of silymarin on renalase gene expression. Silymarin showed anti-fibrotic activity. Meng et al. (2019) attributed this effect to the inhibition of TGF- $\beta 1$ signaling pathway by silymarin. Combined CoQ10 \& Silymarin showed improvement of all studied parameters except insignificant change in body, heart and kidney weights. There were no previous studies discussed the effect of both. Therefore, the obtained results reflected the cumulative action of both with their underlying mechanisms of action which discussed before.

\section{CONCLUSION}

Administration of HFD induced dyslipidemia, heart and kidney injury, oxidative stress, inflammation, fibrosis and significant decrease in renalase gene expression in kidney tissue, while administration of CoQ10 and/or Silymarin induced hypo-lipidimic, cardio-protective, reno-protective, anti-oxidant, antiinflammatory and anti-fibrotic activities, and significant increase in renalase gene expression in kidney tissue. This suggested that CoQ10 and Silymarin provided a protective option for combating CRS through several mechanisms.

\section{ACKNOWLEDGEMENT}

The authors would like to express deep thanks to Prof. Dr. Laila A. Rashed, Biochemistry Department, Faculty of Medicine, Cairo University, for her generous cooperation in biochemical analysis and PCR technique. The authors also would like to acknowledge Dr. Marwa Abd-Elmenam, Pathology Department, Faculty of Medicine (Girls), Al Azhar University, Cairo, Egypt, for her generous help and guidance in the analysis and interpretation of the histological studies. 


\section{REFERENCES}

1. Aebi, H. (1984): Catalase in Vitro. Methods Enzymol., 105: 121 - 126.

2. Athwani, V.; Bhargava, M.; Chanchlani, R. and Mehata, A.J. (2017): Incidence and Outcome of Acute Cardiorenal Syndrome in Hospitalized Children. The Indian Journal of Pediatrics, 1-5.

3. Avci, H.; Epikmen, E.T.; Ipek, E.; Tunca, R.; Birincioglu, S.S.; Akşit, H.; Sekkin, S.; Akkoç, A.N. and Boyacioglu, M. (2017): Protective effects of silymarin and curcumin on cyclophosphamide-induced cardiotoxicity. Exp. Toxicol. Pathol., 69(5):317-327.

4. Bancroft, J. D. and Stevens, A. (1996): Theory and practice of histological techniques. 4th Edition, Pbl. Churchill Livingstone, Edinburgh. 766 pages.

5. Barden, A.E.; Shinde, S.; Burke, V.; Puddey, I.B.; Beilin, L.J.; Irish, A.B.; Watts, G.F. and Mori, T.A. (2018): The effect of n-3 fatty acids and coenzyme Q10 supplementation on neutrophil leukotrienes, mediators of inflammation resolution and myeloperoxidase in chronic kidney disease. Prostaglandins and Other Lipid Mediators, 136:1-8.

6. Bustin, S.A.; Benes, V.; Garson, J.A.; Hellemans, J.; Huggett, J.; Kubista, M.; Mueller, R.; Nolan, T.; Pfaffl, M.W.; Shipley, G.L.; Vandesompele, J. and Wittwer, C.T. (2009): The MIQE guidelines: minimum information for publication of quantitative real-time PCR experiments. Clinical Chemistry, 55(4):611-22.

7. Chen, Q.; Wang, T.; Li, J.; Wang, S.; Qiu, F.; Yu, H.; Zhang, Y. and Wang, T. (2017): Effects of Natural Products on FructoseInduced Nonalcoholic Fatty Liver Disease (NAFLD). Nutrients, 9 (2): 96 -108.

8. Chen, P.P.; Xu, H.L.; Ting-Yue; ZhuGe, D.L.; Jin, B.H.; Zhu, Q.Y.; Shen, B.X.; Wang, L.F.; Lu, C.T.; Zhao, Y.Z. and Li, X.K. (2018): CoQ10-loaded liposomes combined with UTMD prevented early nephropathy of diabetic rats. Oncotarget., 9(14): 11767-11782.
9. Cho, S.; Tripathi, A.; Chlipala, G.; Green, S.; Lee, H.; Chang, E.B. and Jeong, $H$. (2017): Fructose diet alleviates acetaminophen induced hepatotoxicity in mice. PLoS One, 12(8):e0182977.

10. Chou, C.L.; Li, C.H.; Lin, H.; Liao, M.H.; Wu, C.C.; Chen, J.S.; Sue, Y.M. and Fang, T.C. (2018): Role of activating transcription factor 3 in fructose-induced metabolic syndrome in mice. Hypertension Research, 41:589-597.

11. Collinson, P.O.; Boa, F.G. and Gaze, D.C. (2001): Measurement of cardiac troponins. Ann. Clin. Biochem., 38: 423-449.

12. Darvishi-Khezri, H.; Salehifar, E.; Kosaryan, M.; Karami, H.; Alipour, A.; Shaki, F. and Aliasgharian, A. (2017): The impact of silymarin on antioxidant and oxidative status in patients with $\beta$-thalassemia major: A crossover, randomized controlled trial. Complementary Therapies in Medicine, 35: 25-32.

13. Dziedzic, M.; Powrózek, T.; Orłowska, E.; Koch, W.; Kukula-Koch, W.; Gawel, K.; Bednarek-Skublewska, A.; MaleckaMassalska, T.; Milanowski, J.; Petkowicz, B. and Solski, J. (2017): Relationship between microRNA-146a expression and plasma renalase levels in hemodialyzed patients. PLoS One, 12(6): $\mathrm{e} 0179218$.

14. Engelmann, H.; Novick, D. and Wallach, D. (1990): Two tumor necrosis factor-binding proteins purified from human urine. Evidence for immunological cross-reactivity with cell surface tumor necrosis factor receptors. J. Biol. Chem., 265:1531.

15. Farsi, F.; Heshmati, J.; Heshmati, L.; Heshmati, P.; Heshmati, N.M.; Heshmati, A.; Heshmati, A. and Heshmati, M. (2017): Can coenzyme Q10 supplementation effectively reduce human tumour necrosis factor- $\alpha$ and interleukin-6 levels in chronic diseases? Protocol for a systematic review and metaanalysis of randomised controlled trials. BMJ Open, 7(10):e016841.

16. Fatima, S.; Al-Mohaimeed, N.; Arjumand, S.; Banu, N.; Al-Jameil, N. and Al-Shaikh, Y. (2015): Effect of pre- and post-combined multidoses of epigallocatechin gallate and 
coenzyme Q10 on cisplatin-induced oxidative stress in rat kidney. J. Biochem. Mol. Toxicol., 29(2):91-7.

17. França, C.N.; Mendes, C.C. and Ferreira, C.E.S. (2018): Time collection and storage conditions of lipid profile. Braz. J. Med. Biol. Res., 51(3): e6955.

18. Freitag, A.F.; Cardia, G.F.E.; Rocha, B.A.; Aguiar, R.P.; Silva-Comar, F.M.S.; Spironello, R.A.; Grespan, R.; CaparrozAssef, S.M.; Bersani-Amado, C.A. and Cuman, R.K.N. (2015): Hepatoprotective Effect of Silymarin (Silybum marianum) on Hepatotoxicity Induced by Acetaminophen in Spontaneously Hypertensive Rats. EvidenceBased Complementary and Alternative Medicine, 538317: 8-15.

19. Friedewald, W.T.; Levy, R.I. and Fredrickson, D.S. (1972): Estimation of the concentration of low-density lipoprotein cholesterol in plasma, without use of the preparative ultracentrifuge. Clinical Chemistry, 18:499-502.

20. Garjani, A.; Andalib, S.; Biabani, S.; Soraya, H.; Doustar, Y.; Garjani, A. and Maleki-Dizaji, N. (2011): Combined atorvastatin and coenzyme Q10 improve the left ventricular function in isoproterenol-induced heart failure in rat. European Journal of Pharmacology, 666: 135-141.

21. Garrido-Maraver, J.; Cordero, M.D.; Oropesa-? vila, M.; Vega, A. F.; de la Mata, M.; Pav?n, A. D.; de Miguel, M.; Calero, C. P.; Paz, M. V.; Cot?n, D. and S?nchezAlc?zar, J.A. (2014): Coenzyme Q 10 Therapy. Mol. Syndromol., 5:187-197.

22. Hadjiphilippou, S. and Kon, S.P. (2015): Cardiorenal syndrome: review of our current understanding. Journal of the Royal Society of Medicine, 109(1):7-12.

23. Hormozi, M.; Mirzaei, R.; Nakhaee, A.; Payandeh, A.; Izadi, S. and Haghighi, J.D. (2018): Effects of coenzyme Q10 supplementation on oxidative stress and antioxidant enzyme activity in glazers with occupational cadmium exposure: A randomized, double-blind, placebo-controlled crossover clinical trial. Toxicology and Industrial Health, 35(1):32-42.
24. Hu, G.; Liang, W.; Wu, M.; Lai, C.; Mei, Y.; Li, Y.; Xu, J.; Luo, L. and Quan, X. (2019): Comparison of T1 Mapping and T1rho Values with Conventional Diffusion-weighted Imaging to Assess Fibrosis in a Rat Model of Unilateral Ureteral Obstruction. Academic Radiology, 26(1):22-29.

25. Jamila, N.; Khan, N.; Khan, A.A.; Khan, I.; Khan, S.N.; Zakaria, Z.A.; Khairuddean, M.; Osman, H. and Kim, K.S. (2017): In Vivo Carbon Tetrachloride-Induced Hepatoprotective And In Vitro Cytotoxic Activities Of Garcinia Hombroniana (Seashore Mangosteen). Afr. J. Tradit Complement Altern Med., 14 (2): 374382.

26. Jensen, V.S.; Hvid, H.; Damgaard, J.; Nygaard, H.; Ingvorsen, C.; Wulff, E.M.; Lykkesfeldt, J. and Fledelius, C. (2018): Dietary fat stimulates development of NAFLD more potently than dietary fructose in SpragueDawley rats. Diabetol. Metab. Syndr., 24;10:4.

27. Jia, G.; Aroor, A.R.; Whaley-Connell, A.T. and Whaley-Connell, J.R. (2014): Fructose and Uric Acid: Is There a Role in Endothelial Function? Current Hypertension Reports, 16(6):434-440.

28. Kosuru, R.; Kandula, V.; Rai, U.; Prakash, S.; Xia, Z. and Singh, S. (2018): Pterostilbene Decreases Cardiac Oxidative Stress and Inflammation via activation of AMPK/Nrf2/HO-1 Pathway in Fructose-Fed Diabetic Rats. Cardiovascular Drugs and Therapy, 32:147-163.

29. Kwon, D.Y.; Jung, Y.S.; Kim, S.J.; Kim, Y.S.; Choi, D.W. and Kim, Y.C. (2013): Alterations in sulfur amino acid metabolism in mice treated with silymarin: a novel mechanism of its action involved in enhancement of the antioxidant defense in liver. Planta, Med., 79(12): 997-1002.

30. Meng, S.; Yang, F.; Wang, Y.; Qin, Y.; Xian, H.; Che, H. and Wang, L. (2019): Silymarin ameliorates diabetic cardiomyopathy via inhibiting TGF-ק1/Smad signaling. Cell Biol. Int., 43(1):65-72. 
31. Naranjo, M.; Lerma, E.V. and Rangaswami, J. (2017): Cardio-Renal Syndrome: A double edged sword. Disease-aMonth, 63(4): 92-100.

32. Pahari, S.K.; Ghosh, S.; Halder, S. and Jana, M. (2016): Role of Coenzyme Q10 in human life. Research J. Pharm. and Tech., 9(6): 635-640.

33. Park, J.H.; Ku, H.J.; Kim, J.K.; Park, J.W. and Lee, J.H. (2018): Amelioration of High Fructose-Induced Cardiac Hypertrophy by Naringin. Scientific Reports 8: 9464-9474.

34. Rahmani, E.; Jamilian, M.; Samimi, M.; Zarezade, M.M.; Aghadavod, E.; Akbari, E.; Tamtaji, O.R. and Asemi, Z. (2018): The effects of coenzyme Q10 supplementation on gene expression related to insulin, lipid and inflammation in patients with polycystic ovary syndrome. Gynecol. Endocrinol., 34(3):217222.

35. Razavi, B.M. and Karimi, G. (2016): Protective effect of silymarin against chemicalinduced cardiotoxicity. Iran J. Basic Med. Sci., 19:916-923.

36. Schirmeister, J., Willmann, H., Kiefer, H. and Hallauer, W. (1964): For and against the usefulness of endogenous creatinine clearance in functional kidney diagnosis. Deutsche medizinische Wochenschrift., 89: 1640-1647.

37. Sharma, B.; Chaube, U. and Patel, B.M. (2018): Beneficial Effect of Silymarin in Pressure Overload Induced Experimental Cardiac Hypertrophy. Cardiovascular Toxicology, 1-13.

38. Simmons, M. and Brick, J. (1970): Collection of Blood from Orbital Sinus in the Laboratory Mouse: Selection Management.1st ed. Pbl. Prentice- Hall, New Jersey, pp.150 162.

39. Singh, A. (2015): Minocycline modulates the neuroprotective effect of coenzyme q10 against amyloid beta 1-42 induced cognitive dysfunction in rats: Behavioral and biochemical evidence. Alzhiemer's \& Dementia, 11(7): 759761.

40. Skrzypczyk, P.; Przychodzień, J.; MizerskaWasiak, M.; Kuźma-Mroczkowska, E.; Okarska-Napierala, M.; Górska, E.;
Stelmaszczyk-Emmel, A.; Demkow, U. and Pańczyk-Tomaszewska, M. (2017): Renalase in Children with Glomerular Kidney Diseases. Adv. Exp. Med. Biol., 1021:81-92.

41. Suriano, F.; Neyrinck, A.M.; Verspreet, J.; Olivares, M.; Leclercq, S.; Wiele, T.V.; Courtin, C.M.; Cania P.D.; Bindels, L.B. and Delzenne, N.M. (2018): Particle size determines the anti-inflammatory effect of wheat bran in a model of fructose overconsumption: Implication of the gut microbiota. Journal of Functional Foods, 41: 155-162.

42. Tachampa, K.; Lertwanakarn, T.; Atchariyasakchai, P.; Pumpitakkul, V.; Kireewan, S. and Buranakarl, C. (2018): Effects of coenzyme Q10 supplementation on cardiac troponin I level, heart rate variability, and echocardiographic profiles in canine with myxomatous degenerative mitral valve disease: a pilot study. Thai. J. Vet. Med., 48(3): 443452.

43. Ustyol, L.; Demir?ren, K.; Kandemir, I.; Erten, R.; Bulan, K.; Kaba, S.; Demir, N. and Basunlu, M.T. (2017): Comparative Nephroprotective Effects of Silymarin, NAcetylcysteine, and Thymoquinone Against Carbon Tetrachloride-Induced Nephrotoxicity in Rats. Iran Red Crescent Med. J., 19(1):e37746.

44. Vivekanandan, L.; Sheik, H.; Singaravel, S. and Thangavel, S. (2018): Ameliorative effect of silymarin against linezolid-induced hepatotoxicity in methicillin-resistant Staphylococcus aureus (MRSA) infected Wistar rats. Biomed. Pharmacother., 108:1303-1312.

45. Wang, L.; Pan, M.H.; Lo, C.Y.; Zhao, H.; Li, S.; Ho, C.T. and Yang, G. (2018): Antifibrotic activity of polyphenol-enriched sugarcane extract in rats via inhibition of $\mathrm{p} 38$ and JNK phosphorylation. Food Funct., 9(2):951-958.

46. Wu, Y.; Wang, L.; Deng, D.; Zhang, Q. and Liu, W. (2017): Renalase Protects against Renal Fibrosis by Inhibiting the Activation of the ERK Signaling Pathways. Int. J. Mol. Sci., 18(5): 855.

47. Wu, Y.; Wang, L.; Wang, X.; Wang, Y.; Zhang, Q. and Liu, W. (2018): Renalase 
contributes to protection against renal fbrosis via inhibiting oxidative stress in rats. International Urology and Nephrology, 23:1-8.

48. Wybraniec, M.T. and Mizia-Stec, K. (2016): Renalase and Biomarkers of Contrast-Induced Acute Kidney Injury. Cardiorenal Med., 6:2536.

49. Xie, X.W. (2017): Liquiritigenin attenuates cardiac injury induced by high fructose-feeding through fibrosis and inflammation suppression. Biomedicine \& Pharmacotherapy, 86:694-704.

50. Yang, Y.; Zhang, D.M.; Liu, J.H.; Hu, L.S.; Xue, Q.C.; Ding, X.Q. and Kong, L.D. (2015): Wuling San protects kidney dysfunction by inhibiting renal TLR4/MyD88 signaling and NLRP3 inflammasome activation in high fructose-induced hyperuricemic mice. J. Ethnopharmacol., 169:49-59.

51. Yerlikaya, A.; Dagel, T.; King, C.; Kuwabara, M.; Lanaspa, M.A.; AndresHernando, A.; Covic, A.; Manitius, J.; Sag, A.A. and Kanbay, M. (2017): Dietary and commercialized fructose: Sweet or sour? Int. Urol. Nephrol., 49(9):1611-1620.

52. Zhang, W.; Hong, R. and Tian, T. (2013): Silymarines Protective Effects and Possible Mechanisms on Alcoholic Fatty Liver for Rats. Biomol. Ther., 21(4): 264-269. 
تأثير الإنزيم المساعد كيو • ا و السليمارين على التعبير

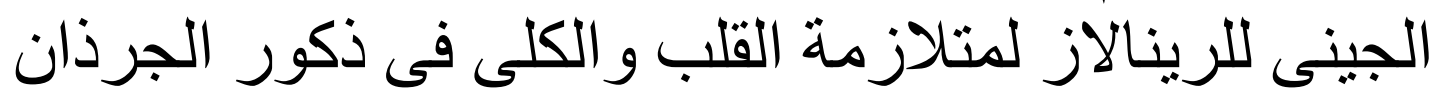

البالغة البيضناء

جيهان أحمد يوسف- منى جمال الدين العنانى- غادة محمد محمد صلاح الدين- سارة نجدى محمود

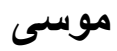

قسم الفسيولوجي- كلية الطب (بنات) -جامعة الأزهر

خلفية البحث : من الأفضل أن توجه الاستر اتيجيات العلاجية في متلازمة القلب و الكلى إلى الروابط

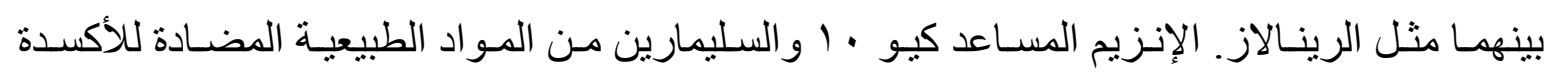

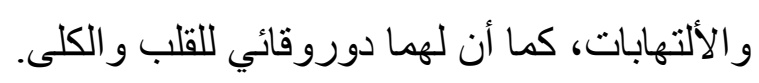

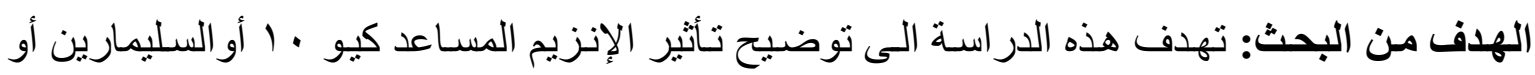

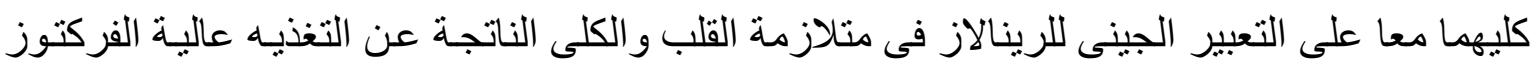
فى ذكور الجرذان البالغة.

المرضي و طرق البحث: تم إجر اء الدراسة الحالية لمدة مأسـابيع علي •0 من ذكور الجرذان البالغة وتم تقسيمهم الى 0 مجمو عات متساوية:

المجموعة الاولى : (مجمو عة ضابطة) تناولت غذاء الجرذان المعتاد وتم اعطاء كل جرذ (مللي من بن برن

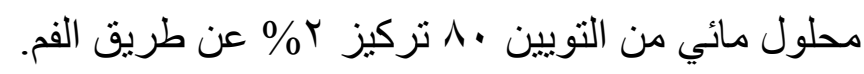
المجموعة الثانية : تناولت تغذية عالية الفركتوز بنسبة. ب٪\% مذاب في الماء.

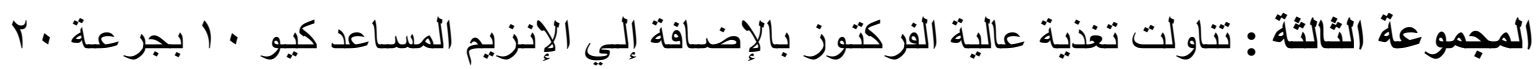
مجم/كجم/اليوم عن طريق الفم.

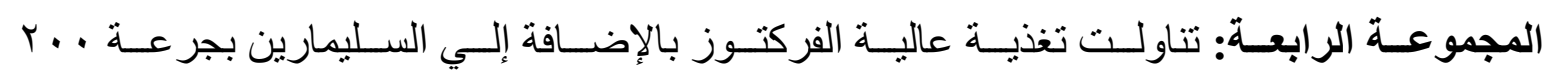
مجم/كجم/اليوم عن طريق الفم.

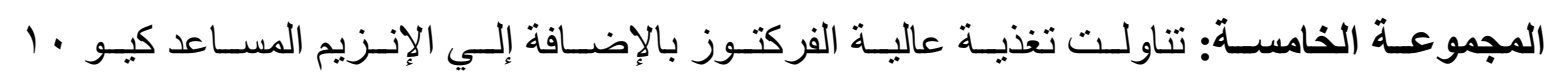
و السليمارين، وتم إعطاؤهم بنفس الجرعات كما ذكر في المجمو عتين السابقتين. 
وفي نهايـة التجربـة تـم تجميـع عينـات الـدم و أنسـجة الكلى وتم قيـاس مسـتويات دهـون الـــم

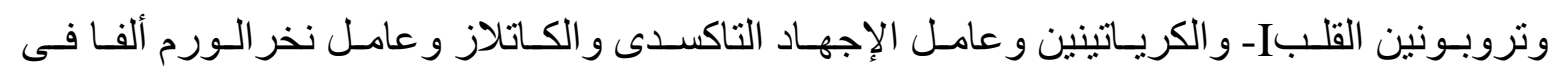
البلازما، و التعبير الجينى للرينالاز فى الكلى، كما تم فحص التليف فى نسيج القلب و الكلى.

النتائج: نتج عن إعطاء الإنزيم المساعد كيو • ـ أو السليمارين أو كليهما معا إنخفاض ذو دلالة إحصـائية فى مستويات دهـون الدم وتروبـونين القلب-I و الكريـاتينين و عامـل الإجهاد التاكسدى و عامـل نخر الورم ألفـا فـى البلازمـا مقارنـة

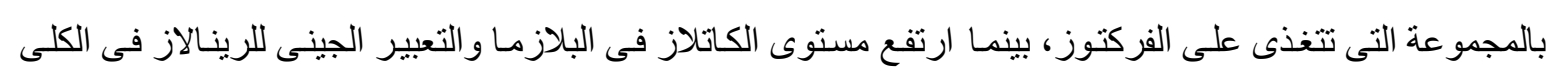

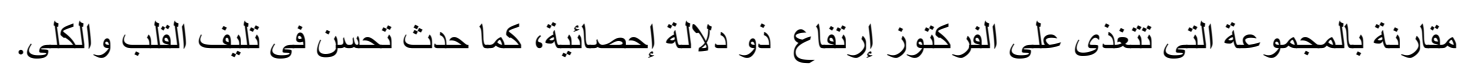
الاستنتاج: نتج عن إعطاء الإنزيم المساعد كيو • ( و السليمارين حماية القلب والكلى وتقليل دهون الدم و الأجهاد

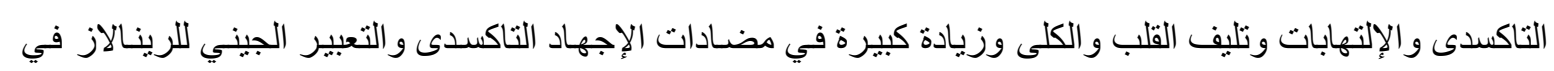
أنسجة الكلى. 